\title{
A study on the corporate social responsibility reports of Greek companies and the use of alternative evaluation methodologies
}

\author{
K. Aravossis \& N. Panayiotou \\ School of Mechanical Engineering, \\ Sector of Industrial Management \& Operational Research, \\ National Technical University of Athens, Greece
}

\begin{abstract}
Over the last decade there has been an apparent shift from adopting more responsible business practices. To demonstrate that they "care" about people and the environment they operate in, organisations have taken different courses of action. The Corporate Social Responsibility (CSR) reports which are annually published, in addition to the traditional annual financial reports, are considered as one of the vehicles used to demonstrate how caring they have been over the ending financial period and how they intend to continue to be even more proactive in the future. This study examines the adoption of CSR practices in Greece as these are described by companies in CSR reports. The CSR disclosures are further classified and the results are analysed and interpreted in order to draw conclusions and to predict the future of CSR in Greece.
\end{abstract}

Keywords: CSR, Greece, case study.

\section{Introduction: CSR \& CSR reporting}

Over the last decade there has been an apparent shift from adopting more responsible business practices (Hancock [1]) as a result of regulatory citations, consumer complaints, and special interest group pressures, to proactive research exploring corporate solutions to social problems and incorporating new business practices that will support these issues. Several factors may be contributing to this shift: evidence that socially responsible business practices can actually increase profits; a global marketplace with increased competition and consumer 
options; interest in increased worker productivity and retention; and increased visibility and coverage of corporate socially responsible (or irresponsible) activities. Most initiatives relate to altering internal procedures and policies, external reporting of consumer and investor information, making provisions for customer access and privacy, and making decisions regarding suppliers and facility and plant locations.

As with any aspect of a business's performance, corporate responsibility needs to be measured if it is to be understood and managed. However, unlike the more traditional performance criteria such as growth, return on capital, profitability, revenue generation, growth of customer base, etc, corporate responsibility cannot be so easily quantified. Indeed, it has been the lack of absolute measurements that has made more difficult the task of bringing responsibility issues and performance to the attention of both the businesses whose behaviour is being considered and the general public whose awareness of this dimension to business performance is essential for any longterm change in attitudes to take effect. There are signs that the Management of companies believe that CSR can be connected with the achievement of improved financial results (Aravosis et al. [2]). Advocates of CSR reports have put forward some perceived benefits, which an organisation may derive from its provision (e.g. Crowther [3]). Typical examples include: increased customer loyalty, more supportive communities, the recruitment and retention of more talented employees, improved quality and productivity and the avoidance of potential reputational risks which may arise from environmental incidents (Idowu and Towler [4]). However, Cooper [5] noted that the practical experience of early adopters of CSR reports was mixed. For example, instead of enhancing companies' reputation, CSR reports attracted adverse comments by drawing attention to divergences between the values espoused by the company and its actual behavior.

The remaining of the paper analyses the CSR initiatives in Greek companies.

\section{Research methodology}

We contacted all companies involved with CSR activities that publish CSR reports. In order to identify such companies, we contacted the most important CSR organizations: Hellenic Network for Corporate Social Responsibility (CSR Hellas), Centre for Sustainability and Excellence (CSE) and Eurocharity. Moreover, the CSR practices of companies listed in the Athens Stock Exchange were analyzed. Also, we contacted selected company executives that had participated in CSR-related conferences in Greece, in order to obtain in depth understanding of their CSR initiatives and obtain information concerning their latest CSR reports. As a result, we came in contact with executives from three international companies. The interviews we had, worked as pilots and helped us to better understand the CSR reality in Greece.

148 companies with registered offices in different parts of Greece were contacted by telephone and/or e-mail in order to obtain information concerning their CSR practices 15 of the contacted companies were members of more than one 
CSR organizations. Our contacts permitted us to identify the companies disclosing CSR information by different methods. Interestingly, some of them offered to send us their organisations' annual reports or suggested putting us through to a more senior individual in the organisation who might be able to help us.

In order to understand how the companies contribute positively to societal lives, the research analysis was designed to highlight the companies' disclosures in industries with insignificant impact on the environment. We received information from 81 companies (about $55 \%$ of the organisations contacted).

Figure 1 summarises the research approach followed, highlighting its distinctive phases and its related activities.

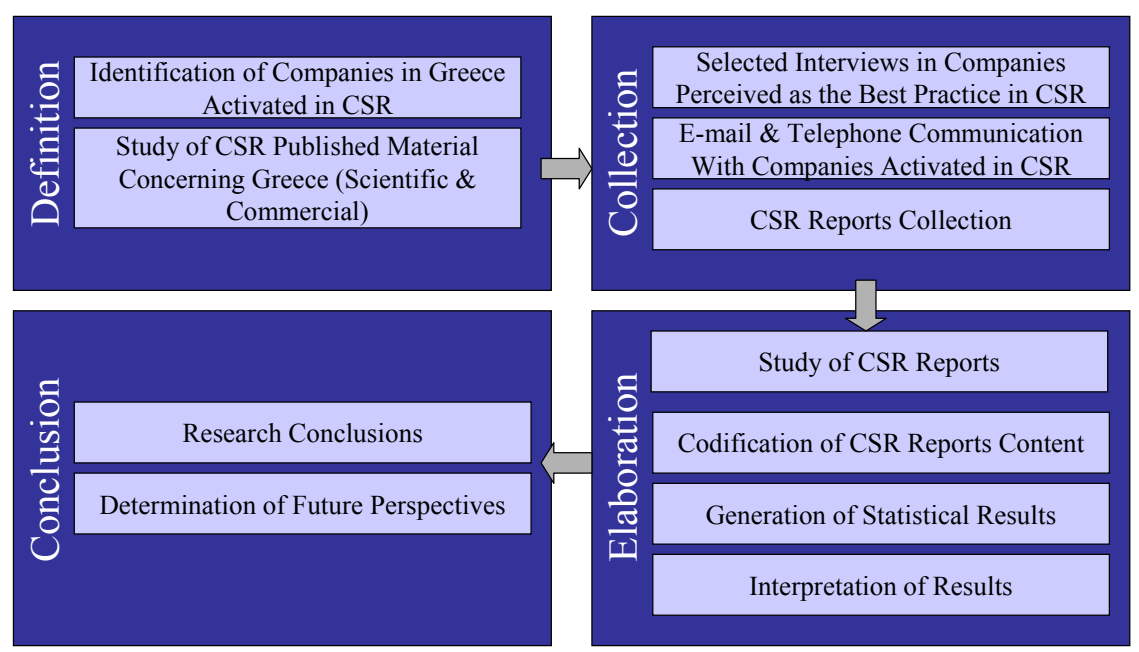

Figure 1: CSR research approach.

\section{Research findings}

From the information received, it was found that 28 organisations report CSR results in Greece. These organisations have adopted two different ways of reporting CSR activities. Some organisations issue a stand-alone CSR report, whilst others devote a section in their corporate annual report for CSR activities.

Table 1 summarises the identified methods used by companies for CSR reporting in Greece.

Another classification of the contacted companies was based on the Organisational Unit, which is responsible for CSR issues. Three different practices were identified in Greece:

- A dedicated CSR Department is responsible for Corporate Social Responsibility: Such a practice shows the importance placed in the CSR processes by the organisation. In the case of Greece, 17 companies have a separated CSR department.

- CSR processes are carried out by the Public Relations Department: Such a practice implies that CSR is seen as an adjunct of Public Relations, a 
function of a company's external relationships, a peripheral activity, not something that needs to be embedded across the organisation horizontally and vertically.

- CSR processes are carried out by another executive: Similarly with the above practice, this one may imply that CSR is perceived as a peripheral activity, with small importance, limited to participating in social and economic regeneration initiatives and supporting the work of charities and voluntary bodies.

Table 1: $\quad$ Methods of CSR reporting of companies operating in Greece.

\begin{tabular}{||l|l||}
\hline \hline $\begin{array}{l}\text { Companies with Stand- } \\
\text { alone CSR Reports }\end{array}$ & $\begin{array}{l}\text { BP, Club Hotel Casino Loutraki, } \\
\text { Coca Cola Hellas, Cosmote } \\
\text { Germanos, Hitachi, HSBC, Johnson }\end{array}$ \\
\& Johnson, Lloyds TSB, \\
Piraeusbank, S\&B, Shell, TIM, TNT, \\
Toshiba, Vodafone, Titan, Athens \\
International Airport, Hellenic \\
Petroleum, Emporiki Bank, Opap, \\
OTE, Friends Provident, Hellenic \\
Exchanges, Italcementi Group
\end{tabular}

Table 2: $\quad$ Organisational unit responsible for CSR processes.

\begin{tabular}{|c|c|c|}
\hline $\begin{array}{llr}\text { Companies With } & \text { an } \\
\text { Independent } & \text { CSR } \\
\text { Organisational Unit } & \end{array}$ & $\begin{array}{l}\text { Companies That } \\
\text { Make Responsible } \\
\text { for CSR the } \\
\text { person in charge } \\
\text { of public relations }\end{array}$ & $\begin{array}{l}\text { Companies that } \\
\text { make responsible for } \\
\text { CSR another } \\
\text { executive }\end{array}$ \\
\hline $\begin{array}{l}\text { Alpha Bank, Cosmote, BP, } \\
\text { OPAP, Vodafone, Hitachi, } \\
\text { Piraeusbank, Toshiba, } \\
\text { Coca-Cola Hellas, TNT, } \\
\text { Titan, } \\
\text { Johnson\&Johnson, Lloyds } \\
\text { TSB, Germanos, HSBC, } \\
\text { Friends Provident }\end{array}$ & $\begin{array}{l}\text { Club Hotel Casino } \\
\text { Loutraki, S\&B, } \\
\text { TIM, Vivartia, } \\
\text { Italcementi Group, } \\
\text { OTE, Hellenic- } \\
\text { Petroleum, } \\
\text { Hellenic } \\
\text { Exchanges }\end{array}$ & $\begin{array}{lr}\text { Siemens, } & \text { Emporiki } \\
\text { bank, } & \text { Athens } \\
\text { International Airport }\end{array}$ \\
\hline
\end{tabular}

Table 2 presents the companies included in the three above categories.

The great majority of the companies that issue a CSR report are international companies. This first approach evinces that the companies that are more active in the field of CSR are companies with a wider range of activation. It follows that 
international companies are more influenced by new trends and also they should demonstrate a good sociable and environmental behavior in order to be sustainable.

Another classification criterion of the companies was their status of ownership. Two different categories were recognised based on this criterion: private organizations and public organizations. The first category includes all companies where the majority of shares belong to private individuals. The second includes all companies where the majority of shares belong to the state. Table 3 displays the fact that the majority of organizations are private, which in combination with the above-mentioned leads to the conclusion that the companies that are innovative in CSR are those that belong to private individuals and their activation surpasses the borders of Greece. It is a little bit suspicious that there are only three public organizations among those that issue CSR reports. Traditionally, public organizations intent to offer to the public more compared to the private ones. The fact that CSR is not so popular among public organizations may have its roots to bureaucracy, which leads to slow adoption of new ideas.

Table 3: Classification of companies according to the status of ownership.

\begin{tabular}{|c|c|}
\hline $\begin{array}{l}\text { Private } \\
\text { Organisations }\end{array}$ & $\begin{array}{l}\text { Vodafone, Titan, Piraeusbank, Vivartia, } \\
\text { Hitachi , TNT, Toshiba, BP, HSBC, } \\
\text { Friends Provident, Italcementi Group, } \\
\text { Shell, S\&B, Siemens, Coca-Cola 3E, } \\
\text { Club Hotel Casino Loutraki, Lloyds } \\
\text { TSB, TIM Hellas, Germanos, Emporiki } \\
\text { Bank, OTE, Johnson \& Johnson, } \\
\text { Cosmote, Alpha Bank, Hellenic } \\
\text { Exchanges }\end{array}$ \\
\hline $\begin{array}{l}\text { Organisations With } \\
\text { Governmental } \\
\text { Participation }\end{array}$ & $\begin{array}{l}\text { Athens International Airport, Hellenic- } \\
\text { Petroleum, OPAP }\end{array}$ \\
\hline
\end{tabular}

Companies were further classified based on their sector of operation. Companies that publish CSR reports in Greece belong to eleven different sectors: telecommunication, financial services, logistics and transportation, industry, cement industry, mining and metals, refinery, distillery, dairies, leisure and entertainment and public agencies. Most companies that issue a CSR report belong to the financial services sector. The telecommunications and manufacturing sectors follow.

Our research also displays that the companies that issue CSR reports are big companies concerning the number of employees they occupy, with a medium size price of 73,455 employees.

Table 4 summarizes the results of the study concerning the CSR practice in Greece as this is revealed by the contents of Corporate Social Responsibility Reports of the analyzed companies. 
Table 4: $\quad$ Summary of CSR findings in Greece.

\begin{tabular}{|c|c|}
\hline Issues & Findings \\
\hline $\begin{array}{l}\text { Number of companies active in CSR } \\
\text { issues in Greece/ Publishing a CSR } \\
\text { Report in Greece }\end{array}$ & $81 / 28$ \\
\hline $\begin{array}{l}\text { Number of companies in Greece/ } \\
\text { Number of companies listed in the } \\
\text { Athens Stock Exchange }\end{array}$ & More than $800,000 / 310$ \\
\hline $\begin{array}{l}\text { Most frequent method of CSR } \\
\text { reporting }\end{array}$ & Stand-alone CSR Reports (25/28) \\
\hline Size of companies & 79,031 employees \\
\hline Scope of operation & $\begin{array}{l}\text { International }(24 / 28) \\
\text { National }(4 / 28)\end{array}$ \\
\hline Regime of ownership & $\begin{array}{l}\text { Private Sector }(25 / 28) \\
\text { Extended Public Sector }(3 / 28) \\
\end{array}$ \\
\hline $\begin{array}{l}\text { Number of companies with CSR reports } \\
\text { listed in Athens Stock Exchange or in } \\
\text { other Stock Exchange }\end{array}$ & $28 / 28$ \\
\hline Dominating Industrial Sectors & 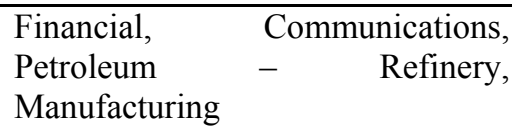 \\
\hline Recognised CSR categories & 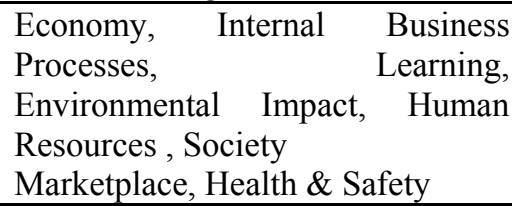 \\
\hline $\begin{array}{l}\text { Dominating Organisational Unit } \\
\text { responsible for CSR }\end{array}$ & $\begin{array}{l}\text { CSR Department } \\
\text { Department of Public Relations }\end{array}$ \\
\hline $\begin{array}{l}\text { Number of different performance } \\
\text { measures used }\end{array}$ & 303 \\
\hline
\end{tabular}

\section{Conclusions}

Despite the diversity of companies and CSR material selected for investigation, it does seem possible to draw carefully some tentative conclusions about CSR practice in Greece.

First, the penetration of CSR in Greece is definitely small so far, a fact proved by the small number of published CSR reports and the small number of companies participating in organisations activated in CSR issues. However, there are indications in the Greek market (identified by personal interviews with CSR experts in Greece) that it will increase in the following years. 
Second, CSR does not appear to be a systematic activity. To the extent that it is not covered by regulations, social disclosure seems to wax and wane in popularity, in the subjects to which it gives attention and in terms of the organizations which provide such disclosure.

A third conclusion of the study in Greece concerning CSR is that its adoption by the companies does appear to be related to certain 'demographic' characteristics. In particular:

- The size of the company plays an important role in its CSR orientation. It was found that large international corporations are the majority of the organisations in Greece that publish CSR reports and disclose CSR-related information in a systematic way. The parameter of international operation is considered as very important revealing that there could be a significant correlation of CSR orientation and the origin of ultimate ownership of the company. This last issues demands further research in the future.

- There is some evidence that the sector of operation affects the degree of CSR adoption. Companies operating in Financial Services, Telecommunications and the Petroleum Industry show a much higher penetration rate compared to all the other sectors. It would be very interesting to further examine the reasons for the behaviour of these sectors.

The classification of performance measures used by companies was a very difficult process of our study. The number of the identified performance measures proves the existing degree of complexity and highlights the luck of:

- A commonly understood definition (within and across companies).

- A common set of benchmarks to measure the attainment of corporate social responsibility.

- Formal established processes in place to achieve these benchmarks.

- A system of internal auditing of the CSR processes.

- A system of external verification by accredited bodies.

It has to be stated, however, that the fact that companies are beginning to accept they have to account in some form for their wider impact on society is a significant step. The methodologies behind these social reports may be poor and their terms of reference self-serving for the company, but the commitment is an important one. As the concepts of corporate social responsibility become more clear and specific, companies will become more sophisticated in their social reporting.

Finally, CSR does not appear to be related to profitability in a documented quantitative way. This finding is not surprising, taking into account the abstract framework of performance measures.

In sum, our empirical study suggests that CSR in Greece is in its infancy phase. Its adopters are mainly large international companies; however, there are aspects of developments in disclosure practices. Some of the companies seem to believe in CSR concepts, others are just following the practices of the best and some appear to use the report as a public relations exercise. CSR reporting needs further improvement as the information it contains needs to be standardized. Taking into account that there is an increasing number of companies in Greece that are truly concerned about the environment, resources, quality of life and 
social matters but are not yet aware of CSR principles, it is believed that the example of CSR reporting by the large and successful companies as well as an official encouragement of social responsibility by the Greek Government in the future will lead the way towards a conscious responsible behaviour of companies operating in Greece.

\section{References}

[1] Hancock, J., Investing in Corporate Social Responsibility - A Guide to Best Practice, Business Planning \& the UK's Leading Companies. London: Kogan Page Ltd, 2005.

[2] Aravossis K., Panayiotou N. \& Tsousi K., A Proposed Methodological Framework for the Evaluation of Corporate Social Responsibility In: K. Aravossis, C.A. Brebbia, E. Kakaras \& A.G. Kungolos, eds. Environmental Economics and Investment Assessment, Southampton UK, WIT Press, pp. 87-95, 2006.

[3] Crowther, D., Corporate social reporting: genuine action or window dressing?, In: D. Crowther, \& L. Rayman-Bacchus, eds. Perspectives on Corporate Social Responsibility, Ashgate, Aldershot, pp. 140-60, 2003.

[4] Idowu S.O. \& Towler B.A., A Comparative Study of the Contents of Corporate Social Responsibility Reports of UK Companies, Management of Environmental Quality: An International Journal, Vol. 15 No. 4, pp. 420437, 2004.

[5] Cooper, B., Corporate social responsibility: the Holy Grail?, Chartered Secretary, July, pp. 12-16, 2003. 